\title{
Palladium-Catalyzed Cross-Coupling Reaction and Gold-Catalyzed Cyclization for Preparation of Ethyl 2-Aryl 2,3-Alkadienoates and $\alpha$-Aryl $\gamma$-Butenolides ${ }^{\dagger}$
}

\author{
Juntae Mo, Hoon Hwang and Phil Ho Lee* \\ Department of Chemistry and Institute for Molecular Science and Fusion Technology, Kangwon National University, \\ Chuncheon 200-701, Korea. *E-mail: phlee@kangwon.ac.kr \\ Received December 14, 2010, Accepted January 8, 2011
}

\begin{abstract}
Efficient synthetic method for the preparation of ethyl 2-aryl-2,3-alkadienoates through Pd-catalyzed selective allenyl cross-coupling reactions of aryl iodides with organoindiums generated in situ from indium and ethyl 4bromo-2-alkynoate was developed. The cyclization reaction of ethyl 2-aryl-2,3-alkadienoates catalyzed by $\mathrm{AuCl}_{3}$ and AgOTf in the presence of $\mathrm{AcOH}$ or TfOH produced various $\alpha$-aryl $\gamma$-butenolides or $\gamma$-substituted $\alpha$ aryl $\gamma$-butenolides.
\end{abstract}

Key Words : Palladium, Gold, Indium, Cross-coupling reaction, Cyclization

\section{Introduction}

Transition metal-catalyzed cross-coupling reactions represent an extremely versatile tool in organic synthesis. ${ }^{1}$ Crosscoupling reactions leading to $\mathrm{C}-\mathrm{C}$ bond formation are often key steps in a wide range of organic processes. ${ }^{2}$ During the past decades, a variety of organometallic reagents, such as alkyl-, allyl-, allenyl-, benzyl-, vinyl- and arylmetals, have been used as nucleophiles in cross-coupling reactions. ${ }^{1}$ Recently, because allenes have been widely used in organic reactions, development of novel synthetic methods of allenes has been required. ${ }^{3}$ Especially, preparation of 2,3alkadienoates is of synthetic importance and still a very challenging problem since they have been utilized in a variety of molecular transformations such as Michael addition, lactonization, cyclization and cycloaddition reactions. ${ }^{3}$ Although several methods for preparation of 2,3alkadienoates are known, ${ }^{4}$ they seem to lack generality as far as 2-aryl substituted analogs are concerned. Traditionally, 2,3-alkadienoates were prepared from reaction of stabilized ylide with derivatives of benzyl bromide followed by treatment of acid chloride in the presence of triethylamine (eq 1). ${ }^{5}$ Unfortunately, this method can not be applied in preparation of alkyl 2-aryl-2,3-alkadienoates because ylide do not react with aryl halide. Gillmann reported silver oxideassisted Pd-catalyzed cross-coupling reaction of Pdcatalyzed cross-coupling reaction of methyl 2-halo-2,3butadienoate with arylboronic acid to produce methyl 2aryl-2,3-butadienoates (eq 2). ${ }^{6}$ However, not only preparation of ethyl 2-halo-2,3-butadienoate but also introduction of substituent on $\gamma$-position is difficult. ${ }^{7}$ Moreover, yield of cross-coupling reaction of methyl 2-halo2,3-butadienoate with phenylboronic acid is variable (Br: 0 $\sim 52 \%$, I: $52 \sim 98 \%$ ). ${ }^{6}$ Recently, Pd-catalyzed cross-coupling reactions using organoindium reagents have been described. ${ }^{8}$

\footnotetext{
This paper is dedicated to Professor Eun Lee on the occasion of his ho-
} nourable retirement.

$$
\text { 年 }
$$

In addition, we reported Pd-catalyzed cross-coupling reactions, ${ }^{9}$ addition reactions, and substitutions ${ }^{10}$ of allylindiums, allenylindiums, 1,3-butadien-2-ylindiums, tetra(organo)indates and indium tri(organothiolates) with a variety of electrophiles. During the course of our research program aimed at finding new indium-mediated organic reactions, ${ }^{11}$ we envisioned the possibility of ethyl 2,3-alkadien-2-yl cross-coupling reactions by using indium and ethyl 4-bromo-2-alkynoates. ${ }^{12}$ Herein, we report that cross-coupling reaction of a variety of aryl iodides with organoindium reagents generated in situ from indium and ethyl 4-bromo-2-alkynoate produced ethyl 2aryl-2,3-alkadienoates with complete regioselectivity and chemoselectivity (Scheme 1). In addition, subsequent treatment of these compounds with gold catalyst gave $\alpha$-aryl $\gamma$-butenolides or $\gamma$-substituted $\alpha$-aryl $\gamma$-butenolides showing antifungal activity (Scheme 1). ${ }^{13}$

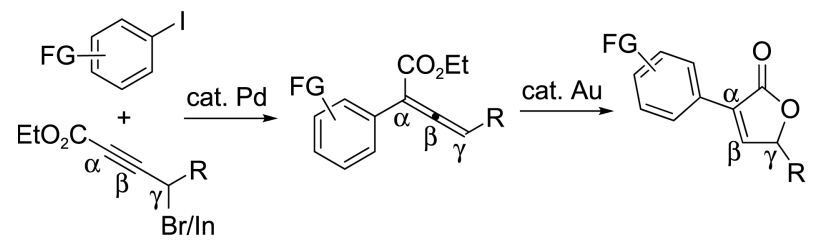

Scheme 1. Preparation of ethyl 2-aryl-2,3-alkadienoates and their cyclization to $\alpha$-aryl $\gamma$-butenolides having $\gamma$-substituent 
Table 1. Optimization of Pd-catalyzed cross-coupling reactions ${ }^{a}$

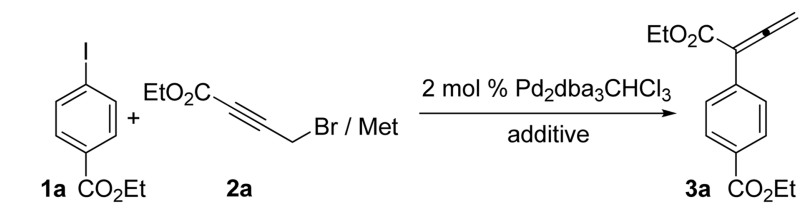

\begin{tabular}{|c|c|c|c|c|c|c|}
\hline Entry & Met & Lignd & Solve & $\begin{array}{c}\text { Additive } \\
\text { (equiv) }\end{array}$ & & $\begin{array}{c}\text { Yield }^{b} \\
(\%)\end{array}$ \\
\hline 1 & In & $16 \mathrm{~mol} \% \mathrm{Ph}_{3} \mathrm{P}$ & DMF & Lil (3) & 18 & 0 \\
\hline 2 & In & $16 \mathrm{~mol} \% \mathrm{Ph}_{3} \mathrm{P}$ & DMF & & 18 & 0 \\
\hline 3 & In & 8 mol \% Xantphos & DMF & Lil (3) & 24 & 0 \\
\hline 4 & In & 8 mol \% Xantphos & THF & Lil (3) & 15 & 0 \\
\hline 5 & In & $8 \mathrm{~mol} \%$ DPEphos & DMF & Lil (3) & 15 & 0 \\
\hline 6 & In & $16 \mathrm{~mol} \%\left(4-\mathrm{CH}_{3} \mathrm{O}-\mathrm{C}_{6} \mathrm{H}_{4}\right)$ & DMF & Lil (3) & 12 & 0 \\
\hline 7 & In & $16 \mathrm{~mol} \%\left(4-\mathrm{CH}_{3} \mathrm{O}-\mathrm{C}_{6} \mathrm{H}_{4}\right)$ & THF & Nal (1) & 12 & 0 \\
\hline 8 & In & $16 \mathrm{~mol} \%\left(4-\mathrm{CF}_{3}-\mathrm{C}_{6} \mathrm{H}_{4}\right)_{3} \mathrm{P}$ & DMF & Lil (3) & 3 & 0 \\
\hline 9 & In & $16 \mathrm{~mol} \%\left(4-\mathrm{CF}_{3}-\mathrm{C}\right.$ & $\mathrm{HF}$ & & 3 & 56 \\
\hline 10 & In & $16 \mathrm{~mol} \%\left(4-\mathrm{CF}_{3}-\mathrm{C}_{6} \mathrm{H}_{4}\right)_{3} \mathrm{P}$ & THF & $\operatorname{Nal}(1.5)$ & 3 & 58 \\
\hline 11 & In & $16 \mathrm{~mol} \%\left(4-\mathrm{CF}_{3}-\mathrm{C}_{6} \mathrm{H}_{4}\right)_{3} \mathrm{P}$ & DMF & $\operatorname{Nal}(1.5)$ & 5 & 0 \\
\hline 12 & In & $16 \mathrm{~mol} \%\left(4-\mathrm{CF}_{3}-\mathrm{C}_{6} \mathrm{H}_{4}\right)_{3} \mathrm{P}$ & THF & $\mathrm{Nal}(1.5)$ & 3 & $79^{c}$ \\
\hline 13 & In & - & DMF & Lil (3) & 10 & $0^{d}$ \\
\hline 14 & $\mathrm{Mg}$ & $16 \mathrm{~mol} \%\left(4-\mathrm{CF}_{3}-\mathrm{C}_{6} \mathrm{H}_{4}\right)_{3} \mathrm{P}$ & THF & $\operatorname{Nal}(1.5)$ & & 0 \\
\hline 15 & $\mathrm{Zn}$ & $16 \mathrm{~mol} \%\left(4-\mathrm{CF}_{3}-\mathrm{C}_{6} \mathrm{H}_{4}\right)_{3} \mathrm{P}$ & THF & $\operatorname{Nal}(1.5)$ & & 0 \\
\hline
\end{tabular}

${ }^{a}$ Reactions performed with In (1 equiv) and $\mathbf{2 a}$ (1.5 equiv). ${ }^{b}$ Isolated yield. ${ }^{\circ} \operatorname{In}\left(1.5\right.$ equiv) and $2 \mathbf{a}$ ( 2.3 equiv) was used. ${ }^{~}{ }^{\circ} \mathrm{Pd}(\mathrm{dppf}) \mathrm{Cl}_{2}$ was used as a catalyst.

\section{Results and Discussion}

Our initial study focused on Pd-catalyzed cross-coupling reactions of ethyl 4-iodobenzoate (1a) with organoindium reagent generated in situ from indium and ethyl 4-bromo-2butynoate $(\mathbf{2 a})^{14}$ (Table 1). Reaction of $\mathbf{1 a}$ with organoindium did not proceed with $2 \mathrm{~mol} \% \mathrm{Pd}_{2} \mathrm{dba}_{3} \mathrm{CHCl}_{3}$ and a variety of ligands such as $\mathrm{Ph}_{3} \mathrm{P}$, Xantphos, ${ }^{15}$ DPEphos, ${ }^{16}\left(4-\mathrm{CH}_{3} \mathrm{O}-\right.$ $\left.\mathrm{C}_{6} \mathrm{H}_{4}\right)_{3} \mathrm{P}$ and $\left(4-\mathrm{CF}_{3}-\mathrm{C}_{6} \mathrm{H}_{4}\right)_{3} \mathrm{P}$ in the presence of $\mathrm{MX}(\mathrm{M}=\mathrm{Li}$ and $\mathrm{Na}, \mathrm{X}=\mathrm{Cl}$ and $\mathrm{I}$ ) as an additive in DMF or THF (entries 1- 8). However, $2 \mathrm{~mol} \% \mathrm{Pd}_{2} \mathrm{dba}_{3} \mathrm{CHCl}_{3}$ and $16 \mathrm{~mol} \%$ (4$\left.\mathrm{CF}_{3}-\mathrm{C}_{6} \mathrm{H}_{4}\right)_{3} \mathrm{P}$ in the presence of $\mathrm{NaI}$ (1 equiv) afforded selectively ethyl 2-(4-ethoxycarbonylphenyl)-2,3-butadienoate $3 \mathrm{a}$ in $56 \%$ yield in $\mathrm{THF}$, indicating that electron poor ligand is better than electron rich ligand (entry $7 v s .9$ ). In addition, comparison of solvents suggests that THF is critically important for a successful reaction (entry $11 v s .12$ ). Of the catalytic systems examined, the best results were obtained with $2 \mathrm{~mol} \% \mathrm{Pd}_{2} \mathrm{dba}_{3} \mathrm{CHCl}_{3}$ and $16 \mathrm{~mol} \%\left(4-\mathrm{CF}_{3}-\mathrm{C}_{6} \mathrm{H}_{4}\right)_{3} \mathrm{P}$ in the presence of $\mathrm{NaI}\left(1.5\right.$ equiv) in THF at $70{ }^{\circ} \mathrm{C}$ for $3 \mathrm{~h}$, producing selectively 3a in 79\% yield (entry 12 ). There is no propargylic cross-coupling product formed. Organoindium generated in situ from indium (1.5 equiv) and 2a (2.3 equiv) gave the best result as a coupling partner. The high selectivity of the present reaction was compared to $\mathrm{Mg}$ and $\mathrm{Zn}$ reagents. Under the optimum reaction conditions, reaction of 1a with 2a (1.8 equiv) and $\mathrm{Mg}$ (1.5 equiv) or $\mathrm{Zn}$ (1.5 equiv) in refluxing THF did not proceed (entries 14 and 15).
To demonstrate the efficiency and scope of the present method, we applied this catalytic system to reactions of a variety of aryl iodides with organoindium reagent generated in situ from indium and ethyl 4-bromo-2-alkynoates (Table 2). Reaction of iodobenzene (1) with $\mathbf{2 a}$ and indium gave selectively ethyl 2-phenyl-2,3-butadienoate (3b) in $85 \%$ yield (entry 1). However, bromobenzene and chlorobenzene did not react with 2a. Electronic variation on the aromatic substituents, such as methoxy, acetyl, formyl, ethoxycarbonyl and $N$-benzylamido group, did not diminish the efficiency and selectivity in $\mathrm{Pd}$-catalyzed cross-coupling reactions (entries 2-9). Treatment of 1c having electron-donating group $(\mathrm{MeO})$ with organoindium produced the desired products 3c in $65 \%$ yield (entry 2). 4-Iodoacetophenone (1d) was subjected to cross-coupling reaction with $2 \mathbf{a}$ and indium, affording $\mathbf{3 d}$ in $81 \%$ yield (entry 3 ). The reaction conditions were mild enough to tolerate a formyl group, which would be incompatible with other organometallic reagents (entry 4). Ethyl iodobenzoate (1a) and $N$-benzyl 4iodobenzamide (1f) worked equally well with organoindium generated in situ from $\mathbf{2 b}$ and indium, producing 2-aryl-2,3pentadienoates (3f and $\mathbf{3 g}$ ) in $79 \%$ and $76 \%$ yields, respectively (entries 5 and 6). Subjecting 1b to ethyl 4bromo-2-heptynoate (2c) and indium provided $\mathbf{3 h}$ in $85 \%$ yield (entry 7). 3-Iodoanisole (1c) turned out to be compatible with the employed reaction conditions, producing $3 \mathbf{i}$ in $64 \%$ yield (entry 8). We were pleased to obtain ethyl 2-(4ethoxycarbonylphenyl)-2,3-heptadienoate $\mathbf{3 j}$ in $77 \%$ yield from the reaction of $\mathbf{1 a}$ with organoindium under the optimum reaction conditions (entry 9). Treatment of vinyl triflate $1 \mathrm{~g}$ with $\mathbf{1 a}$ and indium in the presence of $\mathrm{KBr}(1.5$ equiv) instead of $\mathrm{NaI}$ provided selectively the corresponding products 3k in 63\% yield (entries 10 ).

Next, synthetic utility of 2-aryl-2,3-alkadienoates was demonstrated by applying them in the efficient synthesis of $\alpha$-aryl $\gamma$-butenolides or $\gamma$-substituted $\alpha$-aryl $\gamma$-butenolides which are important skeleton of antifungals. ${ }^{13} \gamma$-Substituted $\alpha$-aryl $\gamma$-butenolides were prepared by Pd-catalyzed crosscoupling reaction of $\alpha$-bromo- $\gamma$-butenolides with arylboronic acid under microwave heating condition (eq 4). ${ }^{17}$ Recently,

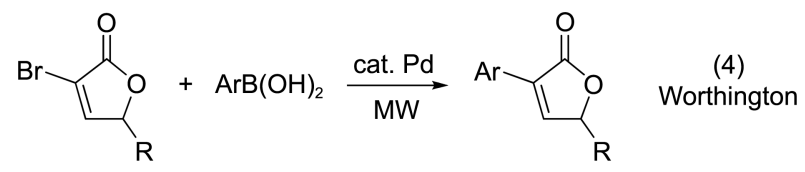<smiles>[R]C=C(C[R])C([R])C[R]</smiles><smiles>[R]C=C([Al])C(=O)OCC</smiles> 
Table 2. Preparation of ethyl 2-aryl-2,3-alkadienoates via Pdcatalyzed cross-coupling reactions with organoindium ${ }^{a}$

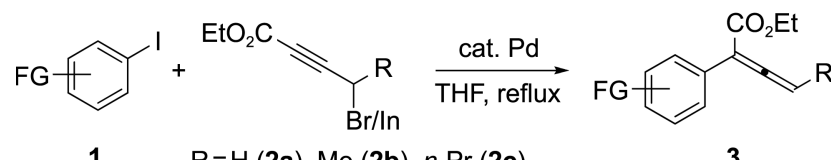

$1 \quad \mathrm{R}=\mathrm{H}(\mathbf{2 a}), \mathrm{Me}(\mathbf{2 b}), n-\operatorname{Pr}(\mathbf{2 c})$

3

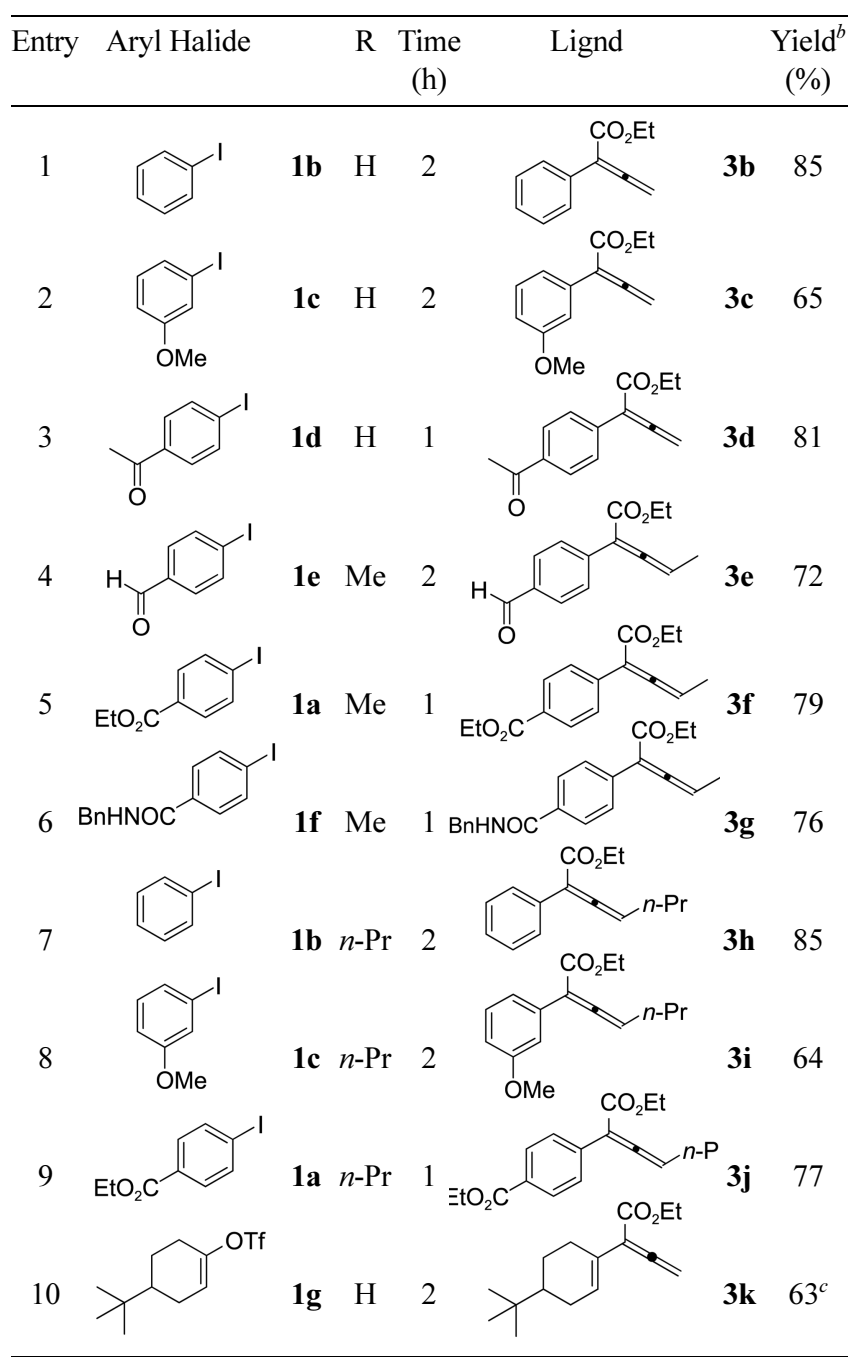

${ }^{a}$ Reactions performed with $2 \mathrm{~mol} \% \mathrm{Pd}_{2} \mathrm{dba}_{3} \mathrm{CHCl}_{3}$ and $16 \mathrm{~mol} \mathrm{\%} \mathrm{(4-}$ $\left.\mathrm{CF}_{3}-\mathrm{C}_{6} \mathrm{H}_{4}\right)_{3} \mathrm{P}$ in the presence of $\mathrm{NaI}$ (3 equiv) in refluxing THF. Organoindium was obtained from In (1.5 equiv) and 2 ( 2.3 equiv). ${ }^{b}$ Isolated yields. ${ }^{c} \mathrm{KBr}$ ( 1.5 equiv) was used instead of NaI.

Shin and Hammond reported gold-catalyzed cyclization of tert-butyl or ethyl 2-methyl or 2-benzyl-2,3-alkadienoates $($ eq 5$) .{ }^{18}$

Encouraged by these and our results related to Aucatalyzed cyclization, ${ }^{10 b, 19}$ the present method was applied in gold-catalyzed cyclization resulting in the formation of $\gamma$ substituted $\alpha$-aryl $\gamma$-butenolides. The results are summarized in Table 3. Although gold-catalyzed cyclization of tert-butyl 2,3-alkadienoates was reported (eq 5), ${ }^{18 a}$ this shows only the synthetic method of $\alpha$-methyl or $\alpha$-benzyl $\gamma$-butenolides because synthesis of 2-aryl-2,3-alkadienoates is impossible. ${ }^{5}$ Reaction of $\mathbf{3 b}$ with a variety of gold catalysts, such as $5 \mathrm{~mol}$
Table 3. Cyclization of ethyl 2-aryl-2,3-alkadienoates catalyzed by gold

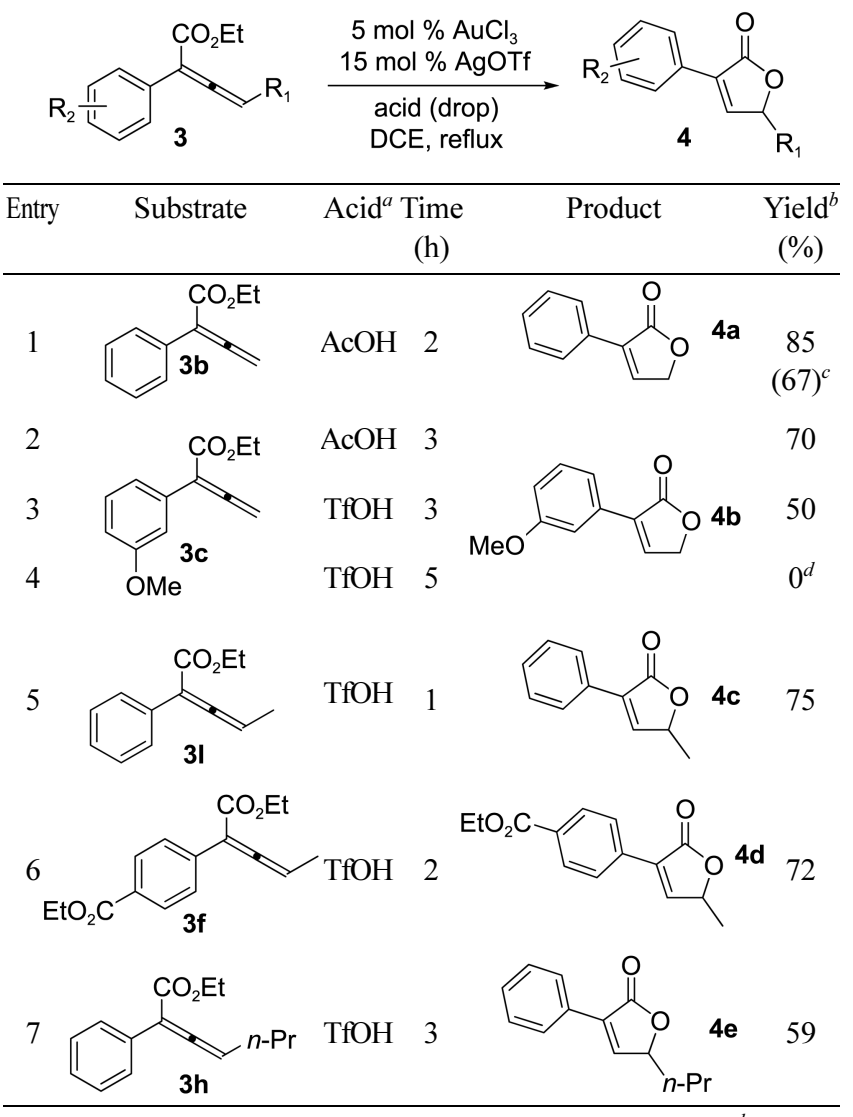

${ }^{a}$ Acid of one drop (ca. $10 \mathrm{~mol} \%$ ) as an additive was used. ${ }^{b}$ Isolated yield. ${ }^{c} 5 \mathrm{~mol} \% \mathrm{AuCl}$ and $5 \mathrm{~mol} \% \mathrm{AgOTf}$ was used as a catalyst. ${ }^{d} \mathrm{Au}$ catalyst was not used.

$\% \mathrm{AuCl}_{3} / 15 \mathrm{~mol} \% \mathrm{AgOTf}, 5 \mathrm{~mol} \% \mathrm{AuCl}_{3} / 15 \mathrm{~mol} \%$ $\mathrm{AgBF}_{4}, 5 \mathrm{~mol} \% \mathrm{Ph}_{3} \mathrm{PAuCl} / 5 \mathrm{~mol} \%$ AgOTf, $5 \mathrm{~mol} \%$ $\mathrm{Ph}_{3} \mathrm{PAuCl} / 5 \mathrm{~mol} \% \mathrm{AgBF}_{4}$ or $5 \mathrm{~mol} \% \mathrm{Ph}_{3} \mathrm{PAuCl} / 5 \mathrm{~mol} \%$ $\mathrm{AgSbF}_{6}$, did not proceed in DCE or $\mathrm{CH}_{2} \mathrm{Cl}_{2}$. However, when alkadienota $\mathbf{3 b}$ was treated with $5 \mathrm{~mol} \% \mathrm{AuCl}_{3}$ and $15 \mathrm{~mol}$ $\%$ AgOTf in the presence of acetic acid (one drop) in DCE $\left(110^{\circ} \mathrm{C}, 2 \mathrm{~h}\right), \alpha$-phenyl $\gamma$-butenolide (4a) was producedin $85 \%$ yield (entry 1 ). The use of $5 \mathrm{~mol} \% \mathrm{AuCl} / 5 \mathrm{~mol} \%$ AgOTf afforded $4 \mathrm{a}$ in $67 \%$ yield. Role of acid in cyclization might accelerate protonation of vinyl gold intermediate that is converted to $\gamma$-butenolide. Under the optimum reaction conditions, 2-(3-methoxyphenyl)-2,3-butadienoate 3c was converted to $\alpha$-(3-methoxyphenyl)- $\gamma$-butenolide in $70 \%$ $(\mathrm{AcOH})$ and $50 \%(\mathrm{TfOH})$ yield (entries 2 and 3). A control experiment with $\mathrm{AcOH}$ or $\mathrm{TfOH}$ (one drop or 1 equiv) in the absence of $\mathrm{AuCl}_{3}$ and AgOTf did not afford the desired product, indicating that gold catalyst is essential for cyclization (entry 4). In the case of 2-aryl-2-alkadienoates (3I and 3f) having methyl group on C4-position, the desired products $(\mathbf{4 c}$ and $\mathbf{4 d})$ was produced in $75 \%$ and $72 \%$ yields, respectively, using TfOH (entries 5 and 6). Alkadienoate $\mathbf{3 h}$ was cyclized by $5 \mathrm{~mol} \% \mathrm{Ph}_{3} \mathrm{PAuCl} / 5 \mathrm{~mol} \%$ AgOTf in the presence of $\mathrm{TfOH}$, producing the corresponding $\gamma$ butenolide $4 \mathrm{e}$ in $59 \%$ yield (entry 7 ). 


\section{Conclusion}

In conclusion, we have developed an efficient synthetic method for the preparation of ethyl 2-aryl-2,3-alkadienoates through Pd-catalyzed selective allenyl cross-coupling reactions of aryl iodides with organoindiums generated in situ from indium and ethyl 4-bromo-2-alkynoate. Because introduction of aryl group to C2-position of 2,3-alkadienoate is difficult, this method would pave a new way to the synthesis of a wide range of functionalized 2-aryl-2,3-alkadienoates. The cyclization reaction of ethyl 2-aryl-2,3-alkadienoates catalyzed by $\mathrm{AuCl}_{3}$ and AgOTf in the presence of $\mathrm{AcOH}$ or $\mathrm{TfOH}$ produced various $\alpha$-aryl $\gamma$-butenolides or $\gamma$-substituted $\alpha$ aryl $\gamma$-butenolides. Because these compounds are important skeleton of antifungals, the study of further applications of this methodology is now underway.

\section{Experimental Section}

Ethyl 2-(4-ethoxycarbonylphenyl)-2,3-butadienoate (3a): To a suspension of $\mathrm{Pd}_{2} \mathrm{dba}_{3} \mathrm{CHCl}_{3}\left(6.2 \mathrm{mg}, 0.6 \times 10^{-2} \mathrm{mmol}\right)$ and $\left(p-\mathrm{CF}_{3}-\mathrm{C}_{6} \mathrm{H}_{4}\right)_{3} \mathrm{P}\left(22.0 \mathrm{mg}, 4.8 \times 10^{-2} \mathrm{mmol}\right)$ in THF $(0.5$ $\mathrm{mL})$ was added ethyl 4-iodobenzoate (1a) $(50.5 \mathrm{~mL}, 0.3$ $\mathrm{mmol}$ ) at room temperature under nitrogen atmosphere. After being stirred for $30 \mathrm{~min}$, organoindium reagent generated in situ from indium $(52.0 \mathrm{mg}, 0.45 \mathrm{mmol})$, sodium iodide (67.5 mg, $0.45 \mathrm{mmol})$ and $2 \mathrm{a}(129.0 \mathrm{mg}, 0.68 \mathrm{mmol})$ in THF $(1.0 \mathrm{~mL})$ was added and the mixture was stirred at $70{ }^{\circ} \mathrm{C}$ for $2 \mathrm{~h}$. The reaction mixture was quenched with saturated $\mathrm{NaHCO}_{3}$. The aqueous layer was extracted with $\mathrm{CH}_{2} \mathrm{Cl}_{2}(3 \times$ $20 \mathrm{~mL}$ ) and the combined organic layers were washed with brine, dried over $\mathrm{MgSO}_{4}$, filtered and concentrated under reduced pressure. The residue was purified by silica gel column chromatography (EtOAc:hexane $=1: 30$ ) to give 3a (62.0 mg, $0.24 \mathrm{mmol}, 79 \%) .{ }^{1} \mathrm{H} \mathrm{NMR}\left(400 \mathrm{MHz}, \mathrm{CDCl}_{3}\right) \delta$ $8.02(\mathrm{~d}, J=8.44 \mathrm{~Hz}, 2 \mathrm{H}), 7.60(\mathrm{~d}, J=8.44 \mathrm{~Hz}, 2 \mathrm{H}), 5.48$ (s, $2 \mathrm{H}), 4.38$ (q, $J=7.09 \mathrm{~Hz}, 2 \mathrm{H}), 4.30$ (q, $J=7.12 \mathrm{~Hz}, 2 \mathrm{H}$ ), $1.39(\mathrm{t}, J=7.09 \mathrm{~Hz}, 3 \mathrm{H}), 1.33(\mathrm{t},, J=7.12 \mathrm{~Hz}, 3 \mathrm{H}) ;{ }^{13} \mathrm{C}$ NMR $\left(100 \mathrm{MHz}, \mathrm{CDCl}_{3}\right) \delta 216.2,166.7,165.9,137.1$, 129.90, 129.86, 128.7, 103.0, 81.1, 61.9, 61.4, 14.7, 14.6; IR (film) 2982, 1953, 1716, 1607, 1447, 1366, 1275, 1104, 1021, $704 \mathrm{~cm}^{-1}$; HRMS (EI) calcd for $\mathrm{C}_{15} \mathrm{H}_{16} \mathrm{O}_{4} \mathrm{M}^{+}$ 260.1049 , found 260.1046 .

3-Phenyl-5H-furan-2-one (4a): $\mathrm{A}$ suspension of $\mathrm{AuCl}_{3}$ $\left(4.5 \mathrm{mg}, 1.5 \times 10^{-2} \mathrm{mmol}, 5 \mathrm{~mol} \%\right)$ and AgOTf (11.6 mg, $\left.4.5 \times 10^{-2} \mathrm{mmol}, 15 \mathrm{~mol} \%\right)$ in DCE $(0.8 \mathrm{~mL})$ was stirred at $25{ }^{\circ} \mathrm{C}$ for $5 \mathrm{~min}$. A solution of ethyl 2-phenyl-2,3butadienoate (3b) $(56.0 \mathrm{mg}, 0.3 \mathrm{mmol})$ in DCE $(0.4 \mathrm{~mL})$ and $\mathrm{AcOH}$ (one drop) were added to catalyst under nitrogen atmosphere. After being stirred for $2 \mathrm{~h}$ at $70{ }^{\circ} \mathrm{C}$, the reaction mixture was quenched with water. The aqueous layer was extracted with $\mathrm{CH}_{2} \mathrm{Cl}_{2}(15 \mathrm{~mL} \times 2)$ and the combined organic layers were washed with water and brine, dried over $\mathrm{MgSO}_{4}$, filtered under reduced pressure. The residue was purified by silica gel column chromatography (EtOAc: hexane = 1:5 ) gave 4a $(41 \mathrm{mg}, 0.26 \mathrm{mmol}, 85 \%) .{ }^{1} \mathrm{H} \mathrm{NMR}$ $\left(400 \mathrm{MHz}, \mathrm{CDCl}_{3}\right) \delta 7.85(\mathrm{~d}, J=4.02 \mathrm{~Hz}, 2 \mathrm{H}), 7.65(\mathrm{t}, J=$
$1.95 \mathrm{~Hz}, 1 \mathrm{H}), 7.45-7.37$ (m, 3H), 4.92 (d, $J=4.02 \mathrm{~Hz}, 3 \mathrm{H})$; ${ }^{13} \mathrm{C}$ NMR $\left(100 \mathrm{MHz}, \mathrm{CDCl}_{3}\right) \delta 172.7,144.8,132.0,129.9$, 129.8, 129.1, 127.4, 70.0; IR (film) 3095, 1747, 1493, 1447, 1345, 1115, 1057, 958, $828 \mathrm{~cm}^{-1}$; HRMS (EI) calcd for $\mathrm{C}_{10} \mathrm{H}_{8} \mathrm{O}_{2} \mathrm{M}^{+} 160.0524$, found 160.0525 .

3-(3-Methoxy-phenyl)-5H-furan-2-one (4b): ${ }^{1} \mathrm{H}$ NMR $\left(400 \mathrm{MHz}, \mathrm{CDCl}_{3}\right) \mathrm{d} 7.65(\mathrm{~s}, 1 \mathrm{H}), 7.45(\mathrm{~d}, J=1.97,1 \mathrm{H})$, $7.41(\mathrm{~d}, J=7.71,1 \mathrm{H}), 7.33(\mathrm{t}, J=7.93 \mathrm{~Hz}, 1 \mathrm{H}), 6.94(\mathrm{~d}, J=$ 8.15, 1H), 4.92 (d, J = $1.97 \mathrm{~Hz}, 2 \mathrm{H}), 3.84(\mathrm{~s}, 3 \mathrm{H}) ;{ }^{13} \mathrm{C}$ NMR $\left(100 \mathrm{MHz}, \mathrm{CDCl}_{3}\right) \delta 172.5,160.1,145.1,131.8,131.2$, 130.1, 119.8, 115.5, 112.8, 69.9, 55.7; IR (film) 2938, 1751, 1601, 1580, 1487, 1347, 1217, 1113, $793 \mathrm{~cm}^{-1}$; HRMS (EI) calcd for $\mathrm{C}_{11} \mathrm{H}_{10} \mathrm{O}_{3} \mathrm{M}^{+} 190.0630$, found 190.0630.

5-Methyl-3-phenyl-5H-furan-2-one (4c): ${ }^{1} \mathrm{H}$ NMR (400 $\left.\mathrm{MHz}, \mathrm{CDCl}_{3}\right) \delta$ 7.87-7.84 (m, 2H), $7.55(\mathrm{~d}, J=1.80 \mathrm{~Hz}$, $1 \mathrm{H}), 7.42-7.38(\mathrm{~m}, 3 \mathrm{H}), 5.16(\mathrm{td}, J=6.83,1.80 \mathrm{~Hz}, 1 \mathrm{H})$, $1.52(\mathrm{~d}, J=6.83 \mathrm{~Hz}, 3 \mathrm{H}) ;{ }^{13} \mathrm{C} \mathrm{NMR}\left(100 \mathrm{MHz}, \mathrm{CDCl}_{3}\right) \delta$ $172.1,149.4,131.8,129.9,129.7,129.1,127.5,19.6$; IR (film) 2981, 1754, 1492, 1449, 1321, 1132, 1112, $972 \mathrm{~cm}^{-1}$; HRMS (EI) calcd for $\mathrm{C}_{11} \mathrm{H}_{10} \mathrm{O}_{2} \mathrm{M}^{+}$174.0681, found 174.0681.

Ethyl 4-(5-methyl-2-oxo-2,5-dihydrofuran-3-yl)benzoate (4d): ${ }^{1} \mathrm{H}$ NMR $\left(400 \mathrm{MHz}, \mathrm{CDCl}_{3}\right) \delta 8.08(\mathrm{~d}, J=6.68 \mathrm{~Hz}$, 2H), $7.94(\mathrm{~d}, J=6.68 \mathrm{~Hz}, 2 \mathrm{H}), 7.68(\mathrm{~d}, J=1.79 \mathrm{~Hz}, 1 \mathrm{H})$, $5.19(\mathrm{td}, \mathrm{J}=6.89,1.79 \mathrm{~Hz}, 1 \mathrm{H}), 4.40(\mathrm{q}, J=7.12 \mathrm{~Hz}, 3 \mathrm{H})$, $1.54(\mathrm{~d}, J=6.89 \mathrm{~Hz}, 3 \mathrm{H}), 1.41(\mathrm{t}, J=7.12 \mathrm{~Hz}, 3 \mathrm{H}) ;{ }^{13} \mathrm{C}$ NMR $\left(100 \mathrm{MHz}, \mathrm{CDCl}_{3}\right) \delta 171.6,166.5,151.2,134.0$, 131.4, 131.1, 130.2, 127.4, 61.6, 19.4, 14.7; IR (film) 2982, $1756,1714,1368,1276,1184,1108,974 \mathrm{~cm}^{-1}$; HRMS (EI) calcd for $\mathrm{C}_{14} \mathrm{H}_{14} \mathrm{O}_{4} \mathrm{M}^{+} 246.0892$, found 246.0894.

3-Phenyl-5-propyl-5H-furan-2-one (4e): ${ }^{1} \mathrm{H}$ NMR (400 $\left.\mathrm{MHz}, \mathrm{CDCl}_{3}\right) \delta$ 7.86-7.84 (m, 2H), $7.55(\mathrm{~d}, J=1.78 \mathrm{~Hz}$, $1 \mathrm{H}), 7.41-7.38(\mathrm{~m}, 3 \mathrm{H}), 5.07-5.03(\mathrm{~m}, 1 \mathrm{H}), 1.80-1.71(\mathrm{~m}$, 2H), 1.58-1.52 (m, 2H), $1.00(\mathrm{t}, J=7.33 \mathrm{~Hz}, 3 \mathrm{H}) ;{ }^{13} \mathrm{C} \mathrm{NMR}$ $\left(100 \mathrm{MHz}, \mathrm{CDCl}_{3}\right) \delta 172.2,148.5,131.9,130.0,129.7$, 129.1, 127.4, 80.8, 36.0, 18.9, 14.3; IR (film) 2961, 1754, 1492, 1449, 1329, 1118, 1028, 965, $795 \mathrm{~cm}^{-1}$; HRMS (EI) calcd for $\mathrm{C}_{11} \mathrm{H}_{10} \mathrm{O}_{2} \mathrm{M}^{+}$202.0994, found 202.0990.

Acknowledgments. This work was supported by the CRI Program (2011-0009011) funded by the National Research Foundation of Korea (NRF) and by the NRF grant funded by the Korea government (MEST) (2009-0087013). This work was supported by the second phase of the Brain Korea 21 Program in 2009. Dr. Sung Hong Kim at the KBSI (Daegu) is thanked for obtaining the MS data. The NMR data were obtained from the central instrumental facility in Kangwon National University.

\section{References}

1. (a) Heck, R. F. Palladium Reagents in Organic Synthesis; Academic Press: New York, 1985 (b) Metal-Catalyzed CrossCoupling Reactions; Diederich, F., Stang, P. J., Eds.; Wiley-VCH: Weinheim, 1998.

2. (a) Torssell, K. G. B. Natural Product Chemistry; Wiley: Chichester, 1983. (b) Thomson, R. H. The Chemistry of Natural Products; Blackie and Son: Glasgow, 1985. (c) Yamamura, K.; 
Ono, S.; Ogoshi, H.; Masuda, H.; Kuroda, Y. Synlett 1989, 18. (d) Roncali, J. Chem. Rev. 1992, 92, 711. (e) Ennis, D. S.; McManus, J.; Wood-Kaczmar, W.; Richardson, J.; Smith, G. E.; Crastairs, A. Org. Process Res. Dev. 1999, 3, 248. (f) Baudoin, O.; Cesario, M.; Guenard, D.; Gueritte, F. J. Org. Chem. 2002, 67, 1199.

3. (a) Krause, N., Hashmi, A. S. K., Eds. Modern Allene Chemistry; Wiley-VCH: Weinheim, Germany, 2004; Vols. 1 and 2. (b) Schuster, H. F., Coppola, G. M., Eds.; Allenes in Organic Synthesis; Wiley-Interscience: New York, 1984.

4. (a) Taylor, E. C.; Robey, R. L.; Mc Killop, A. J. Org. Chem. 1972, 37, 2797. (b) Silveira, A. Jr.; Angelastro, M.; Israel, R.; Totino, F.; Williamsen, P. J. Org. Chem. 1980, 45, 3522. (c) Myrboh, B.; Ila, H.; Junjappa, H. Synthesis 1982, 1100. (d) Moriarty, R. M.; Vaid, R. K.; Ravikumar, V. T.; Hopkins, T. E.; Farid, P. Tetrahedron 1989, 45, 1605. (e) Lang, R. W.; Hansen, H.-J.; Helv. Chim. Acta 1980, 63, 438. (f) Tsuji, J.; Sugiura, T.; Minami, I. Tetrahedron Lett. 1986, 27, 731. (g) Conrads, M.; Mattay, J. Synthesis 1991, 11.

5. Buono, G. Tetrahedron Lett. 1972, 3257.

6. Gillmann, T.; Weeber, T. Synlett 1994, 649.

7. Gillmann, T.; Heckhoff, S.; Weeber, T. Synth. Commun. 1994, 24, 2133.

8. Perez, I.; Sestelo, J. P.; Sarandeses, L. A. Org. Lett. 1999, 1, 1267.

9. (a) Lee, P. H.; Sung, S.-Y.; Lee, K. Org. Lett. 2001, 3, 3201. (b) Lee, P. H.; Sung, S.-Y.; Lee, K.; Chang, S. Synlett 2002, 146. (c) Lee, K.; Lee, J.; Lee, P. H. J. Org. Chem. 2002, 67, 8265. (d) Lee, K.; Seomoon, D.; Lee, P. H. Angew. Chem. Int. Ed. 2002, 41, 3901. (e) Lee, P. H.; Lee, S. W.; Lee, K. Org. Lett. 2003, 5, 1103. (f) Damle, S. V.; Seomoon, D.; Lee, P. H. J. Org. Chem. 2003, 68, 7085. (g) Lee, P. H.; Lee, S. W.; Seomoon, D. Org. Lett. 2003, 5, 4963. (h) Lee, S. W.; Lee, K.; Seomoon, D.; Kim, S.; Kim, H.; Kim, H.; Shim, E.; Lee, M.; Lee, S.; Kim, M.; Lee, P. H. J. Org. Chem. 2004, 69, 4852. (i) Lee, P. H.; Seomoon, D.; Lee, K.; Kim, S.; Kim, H.; Kim, H.; Shim, E.; Lee, M.; Lee, S.; Kim, M.; Sridhar, M. Adv. Synth. Catal. 2004, 346, 1641. (j) Lee, P. H.; Kim, S.; Lee, K.; Seomoon, D.; Kim, H.; Lee, S.; Kim, M.; Han, M.; Noh, K.; Livinghouse, T. Org. Lett. 2004, 6, 4825. (k) Lee, P. H.; Seomoon, D.; Lee, K.; Org. Lett. 2005, 7, 343. (l) Lee, P. H.; Lee, K.; Angew. Chem. Int. Ed. 2005, 44, 3253. (m) Lee, P. H.; Shim, E.; Lee, K.; Seomoon, D.; Kim, S. Bull. Korean Chem. Soc. 2005, 26, 157. (n) Mo, J.; Kim, S. H.; Lee, P. H. Org. Lett. 2010, 12, 424. (o) Lee, P. H.; Lee, K.; Kang, Y. J. Am. Chem. Soc. 2006, 128, 1139. (p) Lee, P. H. Bull. Korean Chem. Soc. 2007, 28, 17. (q) Seomoon, D.; Lee, K.; Kim, H.; Lee, P. H. Chem. Eur. J. 2007, 13, 5197. (r) Lee, J.-Y.; Lee, P. H. Bull. Korean Chem. Soc. 2007, 28, 1929. (s) Seomoon, D.; Lee, P. H. J. Org. Chem. 2008, 73, 1165. (t) Lee, W.; Kang, Y.; Lee, P. H. J. Org. Chem. 2008, 73, 4326. (u) Lee, K.; Lee, P. H. Tetrahedron Lett. 2008, 49, 4302. (v) Lee, J.-Y.; Lee, P. H. J. Org. Chem. 2008, 73, 7413. (w) Kim, S.; Seomoon, D.; Lee, P. H. Chem. Commun. 2009, 1873. (x) Kim, H.; Lee, K.; Kim, S.; Lee, P. H. Chem. Commun. 2010, 46, 6341. (y) Kang, D.; Eom, D.; Kim, H.; Lee, P. H. Eur. J. Org. Chem. 2010, 2330. (z) Lee, P. H.; Park, Y.; Park, S.; Lee, E.; Kim, S. J. Org. Chem. 2011, 76, 760.

10. (a) Lee, P. H.; Kim, H.; Lee, K. Adv. Synth. Cat. 2005, 347, 1219. (b) Lee, P. H.; Kim, H.; Lee, K.; Kim, M.; Noh, K.; Kim, H.; Seomoon, D. Angew. Chem. Int. Ed. 2005, 44, 1840. (c) Lee, P. H.; Kim, H.; Lee, K.; Seomoon, D.; Kim, S.; Kim, H.; Kim, H.; Lee, M.; Shim, E.; Lee, S.; Kim, M.; Han, M.; Noh, K.; Sridhar, M. Bull. Korean Chem. Soc. 2004, 25, 1687. (d) Lee, P. H.; Seomoon, D.; Kim, S.; Nagaiah, K.; Damle, S. V.; Lee, K. Synthesis 2003, 2189. (e) Lee, K.; Kim, H.; Miura, T.; Kiyota, K.; Kusama, H.; Kim, S.; Iwasawa, N.; Lee, P. H. J. Am. Chem. Soc. 2003, 125, 9682. (f) Miura, T.; Kiyota, K.; Kusama, H.; Lee, K.; Kim, H.; Kim, S.; Lee, P. H.; Iwasawa, N. Org. Lett. 2003, 5, 1725. (g) Lee, P. H.; Seomoon, D.; Lee, K.; Heo, Y. J. Org. Chem. 2003, 68, 2510. (h) Iwasawa, N.; Miura, T.; Kiyota, K.; Kusama, H.; Lee, K.; Lee, P. H. Org. Lett. 2002, 4, 4463. (i) K. Bang, K.
Lee, Y. K. Park, Lee, P. H. Bull. Korean Chem. Soc. 2002, 23, 1272. (j) Lee, P. H.; Kim, K.; Kim, S. Org. Lett. 2001, 3, 3205. (k) Lee, P. H.; Lee, K.; Sung, S.-Y.; Chang, S. J. Org. Chem. 2001, 66, 8646. (1) Lee, P. H.; Bang, K.; Lee, K.; Sung, S.-Y.; Chang, S. Synth. Commun. 2001, 31, 3781. (m) Lee, P. H.; Lee, K.; Chang, S. Synth. Commun. 2001, 31, 3189. (n) Lee, P. H.; Bang, K.; Ahn, H.; Lee, K. Bull. Korean Chem. Soc. 2001, 22, 1385. (o) Lee, P. H.; Seomoon, D.; Lee, K. Bull. Korean Chem. Soc. 2001, 22, 1380. (p) Choi, S.; Hwang, H.; Lee, P. H. Eur. J. Org. Chem. 2011, 1351. (q) Lee, K.; Lee, P. H. Bull. Korean Chem. Soc. 2008, 29, 487.

11. (a) Lee, P. H.; Bang, K.; Lee, K.; Lee, C.-H.; Chang, S. Tetrahedron Lett. 2000, 41, 7521. (b) Lee, P. H.; Ahn, H.; Lee, K.; Sung, S.-Y.; Kim, S. Tetrahedron Lett. 2001, 42, 37. (c) Lee, P. H. Bull. Korean Chem. Soc. 2007, 28, 17. (d) Seomoon, D.; A, J.; Lee, P. H. Org. Lett. 2009, 11, 2401. (e) A, J.-M.; Lee, P. H. Bull. Korean Chem. Soc. 2009, 30, 471. (f) Park, J.; Kim, S. H.; Lee, P. H. Org. Lett. 2008, 10, 5067. (g) Park, C.; Lee, P. H. Org. Lett. 2008, 10, 3359. (h) Yu, H.; Lee, P. H. J. Org. Chem. 2008, 73, 5183. (i) Lee, K.; Lee, P. H. Org. Lett. 2008, 10, 2441. (j) Kim, S.; Lee, P. H. Eur. J. Org. Chem. 2008, 2262. (k) Kim, S.; Lee, K.; Seomoon, D.; Lee, P. H. Adv. Synth. Catal, 2007, 349, 2449. (l) Lee, K.; Lee, P. H. Chem. Eur. J. 2007, 13, 8877. (m) Seomoon, D.; Mo, J.; Kang, D.; Eom, D.; Lee, P. H. Bull. Korean Chem. Soc. 2010, 31, 503. (n) Eom, D.; Kim, S. H.; Lee, P. H. Bull. Korean Chem. Soc. 2010, 31, 645. (o) Kim, H.; Shin, D.; Lee, K.; Lee, S.; Kim, S.; Lee, P. H. Bull. Korean Chem. Soc. 2010, 31, 742. (p) Kim, S.; Kang, D.; Shin, S.; Lee, P. H. Tetrahedron Lett. 2010, 51 , 1899.

12. Lee, P. H.; Mo, J. T.; Kang, D.; Eom, D.; Park, C.; Lee, C.-H.; Jung, Y. M.; Hwang, H. J. Org. Chem. 2011, 76, 312.

13. (a) Pour, M.; Spulak, M.; Balsanek, V.; Kunes, J.; Buchta, V.; Waisser, K. Bioorg. Med. Chem. Lett. 2000, 10, 1893. (b) Pour, M.; Spulak, M.; Buchta, V.; Kubanova, P.; Voprsalova, M.; Wsol, V.; Fakova, H.; Koudelka, P.; Pourova, H.; Schiller, R. J. Med. Chem. 2001, 44, 2701. (c) Pour, M.; Spulak, M.; Balsanek, V.; Kunes, J.; Kubanova, P.; Buchta, V. Bioorg. Med. Chem. 2003, 11, 2843. (d) Oh, C. H.; Park, S. J.; Ryu, J. H.; Gupta, A. K. Tetrahedron Lett. 2004, 45, 7039.

14. (a) Crimmins, M. T.; Nantermet. P. G. J. Org. Chem. 1990, 55, 4235. (b) Crimmins, M. T.; Nantermet, P. G.; Trotter, B. W.; Vallin, I. M.; Watson, P. S.; McKerlie, L .A.; Reinhold, T. L.; Cheung, A. W. J. Org. Chem. 1993, 58, 1038. (c) Jordan, R. W.; Villeneuve, K.; Tam, W. J. Org. Chem. 2006, 71, 5830. (d) Trost, B. M.; Ball, Z. T.; Joge, T. J. Am. Chem. Soc. 2002, 124, 7922. (e) Oh, C. H.; Park, S. J.; Ryu, J. H.; Gupta, A. K. Tetrahedron Lett. 2004, 45, 7039. (f) MacInnes, I.; Walton, J. C. J. Chem. Soc. Perkin Trans. II 1987, 1077. (g) Lowe, J. T.; Youngsaye, W; Panek, J. S. J. Org. Chem. 2006, 71, 3639. (h) Cai, G.; Zhu, W.; Ma, Dawei. Tetrahedron 2006, 62, 5697. (i) Cable, J. R.; Tramontano, A.; Midland, M. M. J. Org. Chem. 1980, 45, 28. (j) Rao, K. S.; Mullanti, K.; Reddy, S.; Pal, M.; Iqbal, J. Tetrahedron Lett. 2005, 46, 2287.

15. Xantphos: 4,5-bis(diphenylphosphino)-9,9-dimethylxanthene.

16. DPEphos: bis(2-diphenylphosphinophenyl)ether.

17. Mathews, C. J.; Taylor, J.; Tyte, M. J.; Worthington, P. A. Synlett 2005, 538.

18. (a) Kang, J.-E.; Lee, E.-S.; Park, S.-I.; Shin, S. Tetrahedron Lett. 2005, 46, 7431. (b) Shin, S. Bull. Korean Chem. Soc. 2005, 26, 1925. (c) Hammond, H. J. Am. Chem. Soc. 2008, 130, 17642.

19. 19. (a) Eom D.; Kang, D.; Lee, P. H. J. Org. Chem. 2010, 75, 7447. (b) Lee, P. H.; Kim, S.; Park, A.; Chary, B. C.; Kim, S. Angew. Chem. Int. Ed. 2010, 49, 6806. (c) Kim, S.; Kang, D.; Shin, S.; Lee, P. H. Tetrahedron Lett. 2010, 51, 1899. (d) Park C.; Lee, P. H. Org. Lett. 2008, 10, 3359. (e) Kim S.; Lee, P. H. Adv. Synth. Catal. 2008, 350, 547. (f) Lee, K.; Lee, P. H. Adv. Synth. Catal. 2007, 349, 2092. 